\title{
Innovative Practices in Turkish Education System According to Teacher Perceptions
}

\section{Ferah Güçlü Yılmaz}

Dr., Republic of Turkey Ministry of Education, Turkey, ferahgucluyilmaz7@hotmail.com

\begin{abstract}
The living conditions of the 21 st century have created a new paradigm in education systems. An approach that focuses on producing new and different, effective and beneficial products and services is emerging. Education systems must keep up with this change and support policies and practices that encourage innovation. Teachers bring innovative approaches to the education system to the classroom. Therefore, they play a key role in raising innovative and creative generations. This research evaluates how innovation is defined in the Turkish Education System, innovative management in education, policy, program and teacher training and development practices based on teacher perceptions. The research method is based on literature review and the "semi-structured interview" technique. The purposeful sampling method and maximum diversity principle were used in the research. Attention was paid to criteria such as participating in the "Innovation Awards Evaluator Training" of the Ministry of National Education, receiving various awards for their innovative work, and working in different cities and regions. According to the results of the study, a significant portion of the participants defines innovative approaches in education by associating them with systemic integrity. It was emphasized that stable policies are needed to develop innovative approaches in the education system. At the same time, it was stated that the legal basis of the management processes should be arranged in a way that allows innovative approaches. It was emphasized that administrators and teachers should be allowed to take initiative in developing teaching activities based on innovative approaches in the implementation of the curriculum.
\end{abstract}

Keywords: innovative education, management, policy, teacher training, development

\section{INTRODUCTION}

Globalization approaches support innovative approaches and direct the science and technology policies of Organisation for Economic Co-operation and Development (OECD) countries that are in economic competition. OECD focuses on creativity and exploratory human resources. Institutional approaches and policies based on innovation; ensures the sustainable performance of employees and institutions and the emergence of creative ideas for newly developing needs (Özdaşl1, 2010). The future is less risky for countries and organizations that consistently support innovation.

Innovation is the embodiment of a new idea or invention (Nafgizer, 2006). In other words, it is the application of knowledge to a social and economic benefit from different perspectives and making it marketable (European Commission, 1995). We can see this concept as achieving an innovative result. According to the Oslo guide (2005), innovative approaches in a country should be evaluated by the following indicators:

- Incentives are given to R\&D units

- Reforms for quality education activities

Citation: Güçlü Y1lmaz, F. (2021). Innovative Practices in Turkish Education System According to Teacher Perceptions. Anatolian Journal of Education, 6(1), 175-190. https://doi.org/10.29333/aje.2021.6115a 
- Patented inventions

- International utility models

- Quality scientific articles and studies.

With the Global Innovation Index (KIE) reports published every year, the innovation levels of the world countries are discussed comparatively. Innovation comparison indices and creative work are evaluated. According to 2019 data for Turkey's ability of innovation, it ranks 49th of 126 countries. Turkey, creativity, innovation, invention patents, utility models, as seen by a reduction in the number of scientific publications (Cornell University, 2019).

Another report comparing countries in terms of the relationships between innovation and economic growth is the American National Science Board Report. 2016 ( Report A, 138 countries) and 2018 (Report B, 137 countries) in the report, Turkey are not included in the top 50 in terms of education and innovation criteria. Comparative data are given in Table 1.

Table 1

Comparing Countries Turkey's place in the national science board report

\begin{tabular}{|c|c|c|c|}
\hline & \multicolumn{2}{|c|}{ Report B } & Report A \\
\hline 1. Quality of Education & 101. & 104. & \\
\hline 2. School Management Quality & 108. & 112. & \\
\hline 3. Existence of Specialty Training Services & 93. & 95. & \\
\hline 4. Staff Training & 102. & 101. & \\
\hline 5. Professional Management Assurance & 80. & 81. & \\
\hline 6. Innovation and Sophistication Factors & 66. & 65. & \\
\hline 7. Innovation & 69. & 71. & \\
\hline 8. Innovation Capacity & 74. & 75. & \\
\hline 9. R\&D Expenses & 69. & 70. & \\
\hline Average & 85. & 86. & \\
\hline
\end{tabular}

According to Table 1, The innovation-related indicators are not compatible with the Strategy 2003 document targets of the Ministry of National Education. The innovation and sophistication factors indicator is ranked $66^{\text {th }}$, while the innovation capacity indicator is ranked 74 . These two indicators are also below Turkey's science and technology targets (TÜBİTAK, 2004)

Corporate innovation policies reflect the general cultural values of the society (Ürper, 2008). The active participation of the employees in innovation activities is also affected by their beliefs about innovation (Tzafirir et al., 2003) Innovative policies create a paradigm change in education, shaping the information and communication society as shown in Table 2 (Hesapçığlu, 2009):

Table 2

Comparison of social paradigms

\begin{tabular}{ll}
\hline Industrial Society Paradigm & Information and Communication Society Technology \\
\hline Lessons in the classroom & Individual research activities outside the classroom \\
\hline Passive assimilation & Apprenticeship \\
\hline Working alone & Learning with the team \\
\hline All-knowing teacher & Advisor \\
\hline A fixed content & Dynamic and flexible content \\
\hline Homogeneity & Diversity / Difference \\
\hline
\end{tabular}

(Reference: BYTE Journal, March 1995; Hesapçığlu, 2001, s. 42) 
Today's educational institutions have to present a model that redesigns management, learning and teaching processes (Hesapçığlu, 2001). In this new education model, "innovative stages and success indicators" should be determined well. Education policies should also include preventive measures against factors that may adversely affect the process. To support an innovative culture in schools, education policies should reward success and encourage change that does not allow stagnation. Schools should be provided with opportunities to take risks, make up for mistakes, and support collaboration (Sniukas, 2007). Innovative education policies will increase the performance of schools (Dobni, 2008).

The manager, who is the leader of corporate innovation, is expected to take responsibility for risk and entrepreneurship. Therefore, innovative managers who re-evaluate existing information with different questions and make predictions with limited information keep employees creative by organizing tasks that only give hints (Filiz, 2003). The positive relationship between innovation and leadership (Akkoç et al., 2011) increases the application of innovative ideas to business behavior by stimulating organizational communication processes (Bektaş \& Erdem, 2015).

OECD countries' "21. According to Century Cooperation Organization P21, the main task of schools is to ensure that the learned academic knowledge contributes to the solution of real problems in life (2018). The main purpose of the learning framework developed in 2002 is to provide students with 4C (Critical Thinking, Collaboration, Communication, Creativity) thinking skills. These skills are also considered 21 st-century skills. Some of these skills are; reading comprehension and language skills, mathematical and scientific thinking skills, media and information literacy skills, critical thinking and problem-solving skills, communication and collaboration skills, innovation and creativity skills, selfmanagement and initiative skills, social and cultural skills, leadership and responsibility skills. Reflecting 21st-century skills to education programs will support students to acquire an innovation culture (Odabaş1, 2007). Republic of Turkey Ministry of National Education (MONE), National Quality Training Framework was published in 2014. Since 2018, some changes have been made in training programs based on the Quality Framework. Eight basic competencies have been identified to raise qualified people and improve the quality of education/training (MYK, 2015b, 2015c). These competencies; Communication in the mother tongue, communication competence in foreign languages, mathematical and digital competence, science and technology competence, competence in social and civic skills, learning to learn, taking initiative and entrepreneurship competence, competence to express what one thinks and respect for cultural differences. Teachers who will provide students with these competencies must also have the same competencies. For this purpose, training studies requiring mutual responsibility are carried out based on harmony and cooperation between higher education institutions and schools in teacher education. Research-oriented teacher training and expertise-oriented training programs are organized at the postgraduate level (TNTEE, 2000; OECD, 2009; ETUCE, 2008). For the professional development of teachers, Comenius and Leonardo da Vinci programs, which establish the international mobility and communication networks of the Directorate General of Education and Culture of the European Union, are also supported. At the international level, teacher development training are seen as a part of lifelong learning and career process (ETUCE, 2008), supported (TNTEE, 2000) and perceived as a professional responsibility (OECD, 2009).

Turkey should have the attitude and skills of teachers, prepared by the European Commission "General Teacher Qualification Guideline" are defined by s. These competencies; refers to personal and professional values such as being in professional development, establishing positive relationships with school-family and society, knowing the student, having knowledge of the curriculum and content, mastering the learning and teaching process, learning, monitoring and evaluating students' development (MEB, 2006 ). Turkey's "General Teacher Qualification Guideline", the determination of teacher education and development policy, evaluation and career development in the context of their business success has been regarded as a road map (MOE, 2008).

Anatolian Journal of Education, April 2021 • Vol.6, No.1 
The year 2009 has been determined as the "European Year of Creativity and Innovation". All over the world, it was decided to consider investing in knowledge, re-planning the education system, using rewarding initiatives, creating a strong culture, supporting innovation, thinking globally and developing environmentally friendly economies as priority issues. In the 2020 European Union Strategy, it appears that the Commission of the European Communities is focused on adding value to informational growth in integrated societies and empowering the individual. Therefore, the most important competence expected from school administrators and teachers; In addition to their personal and professional development, it is to support students in realizing their creative and innovative ideas by taking risks (ATEE, 2007). Teachers' creativity should also be supported within education systems, as creativity is the main source of innovation (EU Council, 2008). The creativity factor should be constantly addressed and kept alive in the professional development process of teachers. Turkey, teacher training and development process, universities, conducts based on its cooperation with the private sector and civil society organizations. Innovative teachers who receive leadership training within the scope of the Innovative Teachers Program (PIL-Partners in Learning), implemented in cooperation with the Ministry of National Education and Microsoft, help teachers in their own schools and other schools as "Innovative Teachers Guide". Overall, this program was successful in terms of technology and innovation integration and made a difference for teachers (Yılmaz and Kocasaraç 2010).

In the literature, teachers 'level of using new technologies (Brahier, 2006), the relationship between the acceptance of innovation and their contributions (Hsua, Lub \& Hsuc 2007), teachers' perceptions of innovation (Könings, Gruwel \& Merrienboer 2007), innovation in education (Blandul, 2014), an innovation In publications such as educational robots (Ospennikova, Ershov \& Iljin, 2015) and technological innovation capabilities of university students (Qu and Liang), mostly individual and technological dimensions of the concept of innovation were discussed. information In Turkey, the impact on innovation of knowledge sharing (Demirel and distinguished 2008), Turkey's position in the global innovation index (Tass, 2017), the role of state innovation (Lint, 2020), biology, science and technology teachers (Kaya, 2017; Demir, Böyük \& Koç 2011) and the individual innovation level of faculty members (Bayraktar, 2012), creativity and innovation in teacher education (Özmusul, 2012), and the concept of innovation in publications such as a scale development study on innovative teacher characteristics (Karataş, 2018). It has been dealt with internationally.

\section{Aims of the Research and Research Questions}

No study has been found on how innovation is perceived by teachers in the Turkish Education System (TES). The purpose of this research; To evaluate the definition of innovation, innovative management, policy, program and teacher training-development practices in the Turkish Education System according to the perceptions and suggestions of teachers. This study is expected to contribute to the development of innovative applications in the education system. The research questions:

1. How do teachers explain the concept of "innovation in education"?

2. Do teachers see the "TES" as innovative in terms of education policies? What are his suggestions for this?

3. Do teachers see the "TES" as innovative in terms of education management? What are his suggestions for this?

4. Do teachers see the "TES" as innovative in terms of education programs? What are his suggestions for this?

5. Do teachers see the "TES" as innovative in terms of teacher training and development? What are his suggestions for this? 


\section{METHOD}

This study deals with the opinions and suggestions of teachers regarding the innovations made in the fields of "Education Policies, Educational Management, Education Programs, Teacher Training and Development" in the Turkish Education System between 2005-2018. Innovative studies in education were determined by scanning the literature on innovation. The effects of innovative applications were investigated through a case study, which is one of the qualitative research methods. The "semistructured interview" technique based on one-to-one interaction (Johnson \& Christensen, 2012) was used to determine how teachers are affected by innovative practices and their various, common, or different perceptions.

\section{Participants}

The purposeful sampling method and maximum diversity principle were used in the research. Attention was paid to the criteria stated in Table 3, such as participating in the "Innovation Awards Evaluator Training" of the Ministry of National Education, receiving various awards for their innovative work, and working in different cities and regions. Sampling data are given in Table 3.

Table 3

Distribution of the participants in the sample by branch, seniority

\begin{tabular}{lllllll}
\hline & Branch & \multicolumn{5}{c}{ Seniority } \\
\cline { 2 - 7 } & $\begin{array}{l}\text { Pre-school } \\
\text {-Class (n) }\end{array}$ & $\begin{array}{l}\text { Social-Natural } \\
\text { Science (n) }\end{array}$ & $\begin{array}{l}\text { Vocational } \\
\text { Lesson }(\mathrm{n})\end{array}$ & $\begin{array}{l}0-10 \text { years } \\
(\mathrm{n})\end{array}$ & $\begin{array}{l}11-20 \text { years } \\
(\mathrm{n})\end{array}$ & $\begin{array}{l}21 \text { years/ } \\
\text { above }(\mathrm{n})\end{array}$ \\
\hline Female teacher & 2 & 2 & 1 & 1 & 2 & 2 \\
Male teacher & 3 & 6 & 1 & 3 & 3 & 4 \\
\hline Total & 5 & 8 & 2 & 4 & 515 & 6 \\
\hline General Total & & 15 & & & & \\
\hline
\end{tabular}

Table 3 shows a balanced distribution in the branches and seniority variables of the participants, excluding the gender variable. The distribution of the participants by the branch is as Preschool-Grade (5), Social and Science (8), Vocational Courses (2). It is seen that the distribution of the participants according to professional seniority is 0-10 years (4), 11-20 years (5), 21 and over (6). The data on the education levels of the participants in the sample are given in Table 4.

Table 4

Distribution of the participants in the sample by education levels

\begin{tabular}{lll}
\hline & Graduation level & \\
\cline { 2 - 3 } & Undergraduate $(\mathrm{n})$ & Masters $(\mathrm{n})$ \\
\hline Female teacher & 2 & 3 \\
\hline Male teacher & 3 & 7 \\
\hline Total & 5 & 10 \\
\hline General Total & 15 & 15 \\
\hline
\end{tabular}

Table 4 shows that female participants show a more balanced distribution than male participants in terms of education level variable, and most of the participants have a master's degree. Distribution of the participants according to their place of duty Istanbul (2), Samsun (2), Kayseri (2), Mersin (1), Çanakkale (1), Nevşehir (1), Zonguldak (1), Sakarya (1), Bursa (1), Adana (1), Elazig (1), Bursa (1). The proportion of cities in the sample is approximately $15 \%$. 


\section{Data Collection Tools}

In this study, pre-form and semi-structured interview forms were used for personal information. While developing the data collection tool, document analysis was performed and the data collection tools used in similar studies were examined and evaluated, and the inferences obtained were used in the preparation of the research questions. A pilot study was conducted with 2 volunteer teachers who were not included in the sample, by taking expert opinions about the data collection tool.

\section{Data Analysis}

Themes were formed by determining the common aspects of the raw data obtained from the semistructured interview forms through the informatics program (Kumral \& Saracaloğlu, 2011). The views of the participants were analyzed by dividing them into codes according to their similarities and differences. Data interpreted by making a logical connection are compared with relevant studies. In the tables regarding the findings, themes (T.), codes, how often the codes are expressed $(f)$ and sample quotations are included. While conveying the expressions of the participants, the male teacher was expressed as E.1 and the female teacher as K.1. In the explanations of the tables regarding the findings, the number of people and percentages (number of people, $\%$..) participating in each theme are given.

\section{Validity and Reliability of Data}

The content validity of the data collection tool is based on a comprehensive document review through literature review and expert advice. Interviews with the participants by appointment were recorded in writing and analyzed with their consent. Emphasis was placed on sample size and maximum diversity. To increase the validity and reliability of the data collection tool (Creswell, 2007; Yıldırım \& Şimşek, 2005), the raw texts were divided into themes following the literature review. In the data analysis process, the opinions and suggestions of three academicians who are experts in qualitative research were taken to increase internal reliability. The determining themes and codes were re-evaluated and corrections were made. Eisner'sexplanation', 'interpretation' and 'evaluation' processes (Kumral \& Saracaloğlu, 2011) were followed. The methods and techniques followed in the study to increase external reliability are explained in detail.

Each interview with the participants lasted 75 minutes on average. All interviews were done face to face. The interviews were written by 2 coders. Miles and Huberman's (1994) formula (Reliability = consensus + disagreement) was used to calculate the percentage of consistency and agreement between coders. Similarities and differences were determined by examining how the data in each category were marked by the coders. Similarities and differences between coders are proportioned to the total data. It was expressed as a percentage and transferred to the formula. Differences between coders are mostly the result of using different concepts that mean the same thing. Other differences of opinion in dividing the data into categories and themes were resolved by consensus, taking the opinion of another expert. Accordingly, it was determined that there is between $88 \%$ and $90 \%$ reliability between the categories. According to Yıldırım and Şimşek (2011), 70\% agreement percentage is considered sufficient in the reliability calculation. Analysis methods, theoretical framework and example are explained in detail to ensure the external credibility of the research.

\section{FINDINGS}

\section{Findings on Defining Innovative Educational Approaches}

Regarding the perceptions of the participants about "innovative education" approach two themes were determined; (1) Innovation in the individual goals of education (2) Innovation in the education system. Table 5 contains the findings and example quotes. 
Table 5

Definitions of "innovative training approaches" by participants

\begin{tabular}{|c|c|c|c|c|}
\hline $\mathrm{T}$ & Codes & $\mathrm{n}$ & $\%$ & Example quotes \\
\hline \multirow[t]{6}{*}{1} & $\begin{array}{l}\text { Abide by the } \\
\text { changes }\end{array}$ & 6 & 40 & $\begin{array}{l}\text { K.5. They are approaches that can follow the changes. } \\
\text { K.1. It is to raise individuals who catch the age and keep up } \\
\text { with the times. }\end{array}$ \\
\hline & $\begin{array}{l}\text { Beneficial to the } \\
\text { individual }\end{array}$ & 5 & 33 & $\begin{array}{l}\text { E.5. The purpose of innovation should be to improve the } \\
\text { individual. }\end{array}$ \\
\hline & & & & $\begin{array}{l}\text { K.2. They are approaches that can benefit the development } \\
\text { of the individual. }\end{array}$ \\
\hline & Happy & 2 & 13 & E.2. To raise compatible and happy individuals. \\
\hline & Creative & 2 & 13 & $\begin{array}{l}\text { E.9. The extraordinary thing is to get rid of routines and } \\
\text { raise a thinking individual. }\end{array}$ \\
\hline & Visionary & 2 & 13 & $\begin{array}{l}\text { K.5. It is the education system that raises forward-thinking, } \\
\text { entrepreneurial and competitive individuals. }\end{array}$ \\
\hline \multirow[t]{10}{*}{2} & $\begin{array}{l}\text { Use of innovative } \\
\text { education and }\end{array}$ & 11 & 73 & $\begin{array}{l}\text { E.3. These are the approaches in which new methods and } \\
\text { techniques are brought to the classroom. }\end{array}$ \\
\hline & training techniques & & & $\begin{array}{l}\text { E.7. They are systems where the teacher can bring } \\
\text { innovations to the classroom. }\end{array}$ \\
\hline & & & & $\begin{array}{l}\text { E.10. Innovative systems first produced by the teacher and } \\
\text { turn knowledge into skills are important. }\end{array}$ \\
\hline & Awareness / & 8 & 53 & E.6. It is to reveal the differences. \\
\hline & creating difference & & & $\begin{array}{l}\text { K.3. Education systems should raise awareness of } \\
\text { environmental problems and production. }\end{array}$ \\
\hline & $\begin{array}{l}\text { Presence of teachers } \\
\text { with high }\end{array}$ & 5 & 33 & $\begin{array}{l}\text { E.8. Schools should prepare students for life and develop life skills } \\
\text { K.4. Well-prepared teachers are innovative. }\end{array}$ \\
\hline & $\begin{array}{l}\text { communication } \\
\text { skills and sharing }\end{array}$ & & & $\begin{array}{l}\text { E.7. They are systems that set the teacher free, allow himself } \\
\text { to develop, and communicate between the past and the future. }\end{array}$ \\
\hline & & & & $\begin{array}{l}\text { E.1. They are systems in which the principles of society are } \\
\text { protected and contribute to economic growth and the sharing } \\
\text { of what has been learned. }\end{array}$ \\
\hline & Using technology & 4 & 26 & K.3. They are approaches in which new technologies are used. \\
\hline & Havin a vision & 4 & 26 & $\begin{array}{l}\text { E. } 4 \text {. We call the system that has a certain way to go, } \\
\text { innovative. }\end{array}$ \\
\hline
\end{tabular}

As seen in Table 5; $6(40 \%)$ of the participants think that innovative approaches in education should focus on the individual goals of education. Also, 6 participants; innovative approaches, adapting to changes (40\%), 5 participants; benefiting the individual (33\%), 2 participants; happiness (13\%), 2 participants; creativity (13\%) and 2 participants defined it as visionary (13\%). These definitions are mostly associated with individuality. It is observed that 11 participants do not attach more importance to the innovations to be made in the education system (73\%). At the same time, 11 participants; using innovative education and training techniques (73\%), 8 participants; drew attention to the awareness and difference of innovative approaches (53\%). 5 participants for innovative approaches to be sustainable; teachers have communication skills (33\%), 4 participants; from the development of informatics competencies (26\%) and 4 participants; they mention that they are a visionary (26\%).

\section{Findings Regarding Evaluation of Turkish Education System in Terms of Education Policies}

Regarding the perceptions of the participants abouteducation policies', three themes were determined: (1) Those who expressed the view that education policies were innovative (2) Those who expressed the view that education policies were not innovative (3) Suggestions for education policies to be innovative. Table 6 contains the findings and example quotes. 
Table 6

Findings regarding evaluation of Turkish education system in terms of education policies

\begin{tabular}{|c|c|c|c|c|}
\hline $\mathrm{T}$ & Codes & $\mathrm{n}$ & $\%$ & Example quotes \\
\hline 1 & $\begin{array}{l}\text { Failure of } \\
\text { innovative } \\
\text { approaches in } \\
\text { practice }\end{array}$ & 3 & 20 & $\begin{array}{l}\text { E.5. Unfortunately, teachers or administrators doing new and } \\
\text { different work is not supported } \\
\text { K.2. Education policies are constantly changing, we cannot trust and } \\
\text { act. }\end{array}$ \\
\hline 2 & $\begin{array}{l}\text { Education } \\
\text { Policies are } \\
\text { not innovative }\end{array}$ & 12 & 80 & $\begin{array}{l}\text { E.7. We are not innovative. It is seriously troubled in the legislation } \\
\text { We cannot open the way for the teacher. } \\
\text { E.4. Our short-term education policies are not stable. } \\
\text { E.8. Our training programs always have a certain pattern. Teacher's } \\
\text { contribution in this matter is ignored. } \\
\text { K.5. We are only expected to meet the standard. }\end{array}$ \\
\hline 3 & Innovative & 15 & 100 & K.6. Innovative practices are carried out under personal, political \\
\hline & $\begin{array}{l}\text { Importance } \\
\text { should be } \\
\text { attached to the } \\
\text { development of } \\
\text { the teacher } \\
\text { Coordination } \\
\text { between } \\
\text { universities, } \\
\text { Ministry and } \\
\text { sectors }\end{array}$ & 12 & 80 & $\begin{array}{l}\text { approach and views. } \\
\text { K.1. Innovative policies have no continuity. } \\
\text { E.2. The most innovative approach would be: Educational is } \\
\text { Institutions hould be allowed to set short and long-term goals, } \\
\text { accountability requires this } \\
\text { K.4. The changes made are neither about our culture nor our needs } \\
\text { E.9. Education policies should allow innovative approaches that } \\
\text { strengthen the school. Bureaucracy binds us very much } \\
\text { K.5. A policy based on scientific data should be produced. } \\
\text { E.9. The goal of innovative education policies should be to discover } \\
\text { and develop the potential of the teacher. If the teacher becomes a } \\
\text { visionary leader, he can convey the student. } \\
\text { K.5. Teachers should receive professional development training in } \\
\text { the accordance with requirements of the age } \\
\text { E.7. Professional development training to be offered to teachers } \\
\text { should be adapted by considering the region where teachers work } \\
\text { and the characteristics of the school } \\
\text { E.2 The Ministry should coordinate the education system and all its } \\
\text { parts or allow and control the coordinated work. University-school } \\
\text { collaboration is only possible with consulting academics } \\
\text { K.3.Academics and teachers should work together. }\end{array}$ \\
\hline
\end{tabular}

As seen in Table 6; Only 3 participants (20\%) see education policies as innovative. However, they also noted that innovative policy approaches did not find a complete answer in practice. 12 participants; $(80 \%)$ do not find educational policies innovative. All of the participants to make education policies innovative; drew attention to consistent practices (100\%). 13 Participants; think that continuous investment should be made in the development of teachers (87\%). 12 Participants; It suggests that coordination between the Ministry of Education and economic sectors should be improved (80\%).

\section{Findings Regarding Evaluation of Turkish Education System in terms of Innovative Education Management}

Regarding the perceptions of the participants about "Management of Education" three themes were determined; (1) Those who expressed an opinion that educational management practices are innovative, (2) Those who stated that education management practices were not innovative, (3) Suggestions for educational management practices to be innovative. Table 7 contains the findings and example quotes. 
Table 7

Findings regarding evaluation of Turkish education system in terms of innovative education management

\begin{tabular}{|c|c|c|c|c|}
\hline $\mathrm{T}$ & Codes & $\mathrm{n}$ & $\%$ & Example quotes \\
\hline 1 & $\begin{array}{l}\text { Very few } \\
\text { innovative }\end{array}$ & 2 & 13 & $\begin{array}{l}\text { E.5. Efforts are made to save the day. Everything is left to the } \\
\text { conscience. }\end{array}$ \\
\hline 2 & $\begin{array}{l}\text { Innovative } \\
\text { applications } \\
\text { are risky }\end{array}$ & 12 & 80 & $\begin{array}{l}\text { E.9. Innovation is a system business. It is necessary to take risks } \\
\text { and take initiative. } \\
\text { K.3.Education policies vary according to governments. } \\
\text { Applications are different from time to time. Preserving its current } \\
\text { status is important, innovation means risk, we cannot afford it. } \\
\text { K.5. Innovative approaches are not given importance, everything } \\
\text { changes depending on the personality of the leader. } \\
\text { E.2. What can happen from the management practices of a manager } \\
\text { who does not travel, does not see, does not read. }\end{array}$ \\
\hline 3 & Appointment & 14 & 93 & E.3. If we want innovation, we need a competent manager. \\
\hline & $\begin{array}{l}\text { of qualified } \\
\text { managers } \\
\text { Improving } \\
\text { human resources } \\
\text { and performance }\end{array}$ & 10 & 60 & $\begin{array}{l}\text { E.4. Managers should produce solutions and know the project and } \\
\text { evaluation logic. } \\
\text { K.6. Our managers are drowned in legislation. } \\
\text { E.5. We have a lot of bureaucratic work and a lot of workloads. } \\
\text { K.2. Innovation is possible with cooperative managers, } \\
\text { motivating, have the vision, know science and technology, and support } \\
\text { development. } \\
\text { E.6. Managers should be able to monitor and evaluate and devote } \\
\text { more time to it. } \\
\text { K.6. Powers should be relaxed. } \\
\text { E.3. We need managers who take responsibilities to carry the } \\
\text { learning environments outside of the school. } \\
\text { E.8. Managers do not know clearly what to give importance and } \\
\text { priority, and act intuitively. } \\
\text { E.2. Job descriptions of Provincial and District National Education } \\
\text { Directorates should be made again. }\end{array}$ \\
\hline
\end{tabular}

As seen in Table 7; Only 2 participants interpreted educational management practices as slightly innovative (13\%). 12 participants; stated that educational management practices are not innovative and innovative approaches are closely related to managerial competencies (80\%). At the same time, 12 participants; stated that managers find innovative approaches risky (80\%). 14 participants; think that the employment of qualified managers should be given importance (93\%). 10 participants; stated that qualified managers develop human resources and manage performance effectively (67\%). 9 Participants; stated that the job descriptions of the managers should be renewed and the initiative should be given to them $(60 \%)$.

\section{Findings and Comments for the Evaluation of Turkish Education System in terms of Training Programs}

Regarding the perceptions of the participants about "Training Programs", three themes were determined: (1) Those who stated that the training programs were innovative (2) Those who expressed the opinion that the training programs were not innovative (3) The recommendations made for the innovative education programs. Table 8 contains the findings and example quotes. 
Table

Findings and comments for the evaluation of Turkish education system in terms of training programs

\begin{tabular}{|c|c|c|c|c|}
\hline $\mathrm{T}$. & Codes & $\mathrm{n}$ & $\%$ & Example quotes \\
\hline \multirow[t]{3}{*}{1} & Optional & 5 & 33 & E.7. We are innovative in terms of our optional lessons diversity. \\
\hline & lessons diversity & & & $\begin{array}{l}\text { K.2. The program has an innovative side, but textbooks are not } \\
\text { enough. }\end{array}$ \\
\hline & $\begin{array}{l}\text { Ability to develop } \\
\text { projects }\end{array}$ & 3 & 20 & $\begin{array}{l}\text { E.5. We implement project-based learning, but it is impossible to } \\
\text { say this for all teachers. }\end{array}$ \\
\hline \multirow[t]{10}{*}{2} & Being exam-oriented & 13 & 87 & $\begin{array}{l}\text { K.6. The information is based on memorization. Our practices } \\
\text { and activities are few } \\
\text { E.1. It does not meet the needs of the individual and society. } \\
\text { E.4. We are always exam-oriented. }\end{array}$ \\
\hline & It does not include & 11 & 73 & E.8. Optional lessons cannot be taught systematically. \\
\hline & innovative & & & The schedules of other classes are so intense. \\
\hline & applications & & & Gains should be reduced, more efficiency should be done. \\
\hline & & & & E.5. The program is very theoretical. \\
\hline & & & & E.4. We are not expected to encourage creativity and curiosity. \\
\hline & Optional lessons are & 10 & 67 & K.4. We do not have optional lessons suitable for our regions. \\
\hline & ignored & & & Optional lessons not have a proper Schedule. \\
\hline & & & & Make up for other lessons. \\
\hline & & & & $\begin{array}{l}\text { K.5. There are no optional lessons in primary schools, free } \\
\text { activities are left to the student's preferences. }\end{array}$ \\
\hline \multirow[t]{13}{*}{3} & Must be a process & 13 & 87 & E.5. The education period is not rich in content, you should see \\
\hline & oriented program & & & children running into school and walking out. \\
\hline & $\begin{array}{l}\text { Optional lessons, } \\
\text { characteristics of the }\end{array}$ & 13 & 87 & $\begin{array}{l}\text { K.3. Optional lessons should have an equivalent in daily life and } \\
\text { should not be chosen as compulsory. It should be able to provide }\end{array}$ \\
\hline & school district and & & & a sweet competition. The courses will be innovative and creative \\
\hline & school type & & & if they are taught with a product focus. \\
\hline & should be determined & & & E.8. Optional lessons must have their specialist teachers. \\
\hline & by considering & & & $\begin{array}{l}\text { E.6. Programs that arouse curiosity and lead to research and } \\
\text { product production should be made. }\end{array}$ \\
\hline & & & & $\begin{array}{l}\text { K.6. We must keep track of time. New knowledge is produced } \\
\text { every day in the field of biology and chemistry. Our curricula } \\
\text { should be integrated, unnecessary gains should be made. }\end{array}$ \\
\hline & $\begin{array}{l}\text { Special time should } \\
\text { be reserved for } \\
\text { social, sportive and }\end{array}$ & 11 & 73 & $\begin{array}{l}\text { K.3. Achievements should be absorbed into free activities, social, } \\
\text { and sportive activities and should be used in lessons with } \\
\text { activities that will reveal skills. }\end{array}$ \\
\hline & artistic activities & & & $\begin{array}{l}\text { E.8. Our schools should switch to single learning as soon as } \\
\text { possible and the afternoons should be reserved for social and } \\
\text { sports activities. }\end{array}$ \\
\hline & Initiative & 9 & 60 & E.9. Students should be taught the transfer of knowledge, teachers \\
\hline & should be used in & & & should be left free in this regard. \\
\hline & $\begin{array}{l}\text { the implementation } \\
\text { of the program }\end{array}$ & & & $\begin{array}{l}\text { K.1. Teachers should be able to take initiative in teaching the } \\
\text { program outcomes, in terms of methods and techniques... }\end{array}$ \\
\hline
\end{tabular}

As seen in Table 8; 5 Participants see optional lessons diversity as sufficient in terms of innovation (33\%). 3 Participants; found training programs innovative in terms of project development (20\%). 13 Participants; $(87 \%)$ think that the aim of educational programs is to prepare students for exams. 11 Participants; stated that innovative approaches were not used in the implementation of the programs (73\%). 10 Participants; It was pointed out that the elective courses in which creativity and talent emerged were ignored (67\%). 13 Participants; He thinks that the geographical environment of the school and the characteristics of the school type should be taken into account in the preparation of educational programs and determination of elective courses (87\%). 11 Participants; 9 participants 
mentioned that special time should be devoted to social, sports and artistic activities $(73 \%)$ and that more attention should be given to entrepreneurship (9\%, 60\%).

\section{Findings Regarding Evaluation of Turkish Education System in Terms of Teacher Training and Development}

Regarding the perceptions of the participants on 'Teacher Training and Development (TTD)', two main themes have been identified: (1) Those who stated that TTD approaches are not innovative (2) Suggestions for the renewal of TTD approaches: Table 9 contains the findings and example quotes.

Table 9

Findings regarding evaluation of Turkish education system in terms of teacher training and development

\begin{tabular}{|c|c|c|c|c|}
\hline T. & Codes & $\mathrm{n}$ & $\%$ & Example quotes \\
\hline \multirow[t]{5}{*}{1} & $\begin{array}{l}\text { Education faculties } \\
\text { are not } \\
\text { innovative }\end{array}$ & 15 & 100 & $\begin{array}{l}\text { E.6. Teacher candidates do not receive an education with an } \\
\text { understanding that will bring innovation to educational } \\
\text { practices. } \\
\text { K.3. Teacher candidates graduate without doing enough } \\
\text { fieldwork. } \\
\text { E.2. Education programs at universities are not innovative } \\
\text { K.4. There is a serious miscommunication between the university } \\
\text { and the Ministry of Education }\end{array}$ \\
\hline & $\begin{array}{l}\text { Lack of coordination } \\
\text { between universities }\end{array}$ & 14 & 93 & $\begin{array}{l}\text { K.1. Educators providing professional development training are } \\
\text { very inadequate. }\end{array}$ \\
\hline & and the Ministry & & & E.2. Academics are not at all effective in developing teachers. \\
\hline & $\begin{array}{l}\text { of Education in } \\
\text { the teacher }\end{array}$ & & & $\begin{array}{l}\text { K.5. The universities of each province and relevant academicians } \\
\text { do not take responsibility for the development of the teacher. }\end{array}$ \\
\hline & $\begin{array}{l}\text { development } \\
\text { training }\end{array}$ & & & $\begin{array}{l}\text { E.5. Professional development training is often not suitable for } \\
\text { the schools we work at or the class level. }\end{array}$ \\
\hline \multirow[t]{20}{*}{2} & Collaborative & 15 & 100 & E.8. Teachers should be well chosen for the profession so that \\
\hline & coordination & & & they can be well educated. \\
\hline & between & & & K.7. Teaching skills cannot be measured by a written exam. \\
\hline & education & & & E.6. Innovation is the link between theory and practice. Teachers \\
\hline & faculties, the & & & should be developed by combining vision and capacity. Teacher \\
\hline & Ministry of & & & competencies should be determined in all branches. \\
\hline & $\begin{array}{l}\text { Education and } \\
\text { teachers should be }\end{array}$ & & & $\begin{array}{l}\text { E. } 4 \text {. Pre-service training should be workshops that combine } \\
\text { theory and practice. }\end{array}$ \\
\hline & developed & & & K.1. Teaching practices should start from the 2 nd grade. \\
\hline & & & & $\begin{array}{l}\text { K.6. The content of professional development training should be } \\
\text { enriched. Teachers should go abroad and develop their } \\
\text { visions. }\end{array}$ \\
\hline & & & & $\begin{array}{l}\text { K.5. Not every teacher who wants to attend professional } \\
\text { development training. }\end{array}$ \\
\hline & & & & $\begin{array}{l}\text { E.7. There is a certain quota. Teachers are not chosen fairly } \\
\text { for these training. In the development of teachers, the school }\end{array}$ \\
\hline & & & & the principal should be given initiative and school principals should \\
\hline & $\begin{array}{l}\text { Activity-based } \\
\text { professional } \\
\text { and mandatory }\end{array}$ & 13 & 87 & $\begin{array}{l}\text { E.2. Every teacher must be subject to compulsory development } \\
\text { programs. Arts, sports, etc. activities should also be considered } \\
\text { as a direction that improves the teacher. }\end{array}$ \\
\hline & There should be & & & E.7. Developer videos should be prepared in the form of a public \\
\hline & $\begin{array}{l}\text { professional } \\
\text { development }\end{array}$ & & & $\begin{array}{l}\text { spot Institutions providing professional development training } \\
\text { should be established in each province. }\end{array}$ \\
\hline & programs & & & K.1. Colleague circles should be established. The school \\
\hline & & & & the principal should be the teaching leader. \\
\hline & & & & E.3. Encouraging policies and certificates should be developed \\
\hline & & & & $\begin{array}{l}\text { for teachers to focus on their development. Support should } \\
\text { be obtained from accredited independent institutions. }\end{array}$ \\
\hline & & & & Colleague sharing should be increased \\
\hline
\end{tabular}


As seen in Table 9; It is observed that not all participants find the TTD studies innovative. All of the participants think that prospective teachers graduated without knowing the schools and classes and that education faculties were not innovative (100). 14 Participants; stated that there is a lack of coordination between universities and the Ministry of National Education in teacher training activities (93\%). All participants drew attention to the need for cooperative coordination between education faculties, the Ministry of Education, and teachers (100\%). 13 Participants; stated that professional development should be done more effectively and mandatory professional development areas for teachers should be determined $(87 \%)$.

\section{DISCUSSION}

Innovative educational approaches have been defined by the majority of teachers within the educational system integrity rather than individual studies. This finding supports the results that innovation should be structured within the system as a feature of corporate culture (Dobni, 2008; Herzog, 2011). In addition, there is an agreement between the concepts expressed in sub-themes regarding the concept of innovation in the education system and the innovation definitions of EU and OECD countries (TÜSİAD, 2003). It is seen that especially innovative approaches towards individual goals of education are defined based on 21st-century basic skills (P21, P4C).

The majority of teachers do not see educational policies as innovative. Administrators and teachers are not consistently supported. Coordination should be established between the Ministry of Education and the sectors. This finding supports the research results showing that new ideas, creativity and qualified human resources develop when the support of senior management is provided (Günsel \& Pelenk, 2017). Findings regarding the importance of teacher development are consistent with the inferences stated by the Association for Teacher Education in Europe (ATEE, 2007) regarding the need to empower administrators and teachers.

In terms of educational administration practices, most of the teachers stated that there is a positive relationship between innovative approaches and managerial competencies. This finding supports the result of the research conducted by Karataş, Gök, and Özçetin (2015) that managers attach more importance to innovation as their competencies increase. The views of the participants that especially managers should be able to take the initiative to coincide with the basic principles of the 2020 European Union Strategy. The finding that educational management practices are not innovative is also supported by Bülbül's (2012) finding that school administrators consider themselves less sufficient than others in the process of developing innovative strategies in the innovation management process. Also, teachers stated that qualified managers develop human resources and manage performance effectively. This finding is supported by the research results (Günsel \& Pelenk, 2017), in which the innovative human resources management of the managers paves the way for innovative approaches more. As stated in the suggestions of the participants, school administrators can contribute to the creation of an innovative culture in the management process by creating an increasing number of professional development plans for teachers (EURYDICE, 2013).

Training programs have not been seen as innovative by the majority of teachers. In addition, suggestions on the importance of optional lessons that support students' innovation and creativity support studies in which optional lessons have an impact on student development (Alkan \& Erdem, 2011; Uz \& Uz, 2018). In addition, most of the participants stated that teachers do not use innovative approaches. This finding supports some studies (Sarı, 2011; Demir, Böyük \& Koç, 2011) which stated that the in-process practices suggested in the curriculum were not done by teachers or were not done by students. Also, it can be said that the criticisms and suggestions for the training programs to be innovative include eight key competencies specified in Turkey MYK, 2015b and 2015c. 
None of the teachers found teacher training and development practices innovative. This finding supports the results of research conducted in the field of teacher training in education faculties (Balkar \& Şahin 2014; Ayvaz, 2012; Y1ldırım, 2010). The content, quality and implementation process of teachers' professional development training is also criticized. These findings support the publications showing that individual characteristics such as reflective thinking, autonomy, responsibility and creativity are not given importance in the professional development of teachers (UNESCO, 2002; Usluel, Mumcu \& Demiraslan, 2007). It also supports the studies that put forward the need for the development of teachers through the integration of information technologies into education (European Commission, Directorate General of Education and Culture, 2010; Çiftçi, Taşkaya and Alemdar 2013).

\section{CONCLUSION AND SUGGESTION}

Innovative approaches in education should be implemented with systematic changes. It is important and necessary to think of innovation as a political strategy for education systems to support innovative approaches. Educational policies targeting innovative approaches, developing strategies, analyzing scientific data will reflect positively on administrators and teachers. Social and artistic optional lessons that foster creativity should be given importance. Education faculty academicians have an important role in ensuring the professional development of teachers. The most important concept that emerged in almost every finding of the study was "initiative". School administrators should be able to take initiative to support innovative practices and guide teachers' professional development. Teachers should be able to use initiative to implement different activities in student development. Based on this research, the following recommendations can be developed:

1. Turkey, innovative approaches to manage processes within the education system should go into a restructuring process and should produce consistent policies.

2. Turkey changes to teachers to be used in the course of that initiative should be carried out to support innovative approaches in a legal context.

3. Turkey, it should be supported in the legal sense to use initiative in innovative practices of school administrators.

4. Turkey, improve teacher training and further education should be based on innovative approaches.

5. Turkey, within the education system, should attach importance to the development of innovative and creative ideas for elective courses.

6. Turkey, administrators and teachers, must support and encourage innovative and creative ideas.

7. Turkey, administrators and teachers to share innovative and creative work and should increase support and incentives for the promotion.

8. Turkey, teachers and administrators, with different institutions and organizations in order to carry out innovative and creative work to establish partnerships should support and encourage.

\section{REFERENCES}

Akkoç, İ. Turunç, Ö. \& Çalışkan, A. (2011). Impact of development culture and leadership support on innovative behavior and job performance: the mediating role of work-family conflict. Industrial Relations and Human Resources Journal, 13(4), 86-114.

Alkan, F. \& Erdem, E. (2011). The effect of optional lessons on candidate teachers' level of social skills. Procedia Social and Behavioral Sciences, 15, 3451-3455. 
ATEE (2007). Response from the Association for Teacher Education in Europe to the Public Consultation on Schools for the 21st Century. http://www.atee1.org/publications/3/response_to_the_commission_039_s_public_cons ultation_on_schools_for_the_21st_century.

Ayvaz, D. M. (2012), The effectiveness of induction program for candidate teachers. (Unpublished master thesis). ODTÜ, Ankara.

Balkar, B. \& Şahin, S. (2014), The opınıons of educators on implementıng mentorshıp program for novice teachers. The Journal of Academic Social Science Studies International Journal of Social Science, 29, 83-100.

Bayraktar, D. M. (2012). The individual innovation levels of lecturers and their adoption of web 2.0 tools. Journal of Hasan Ali Yücel Faculty of Education, 35-47.

Bektaş, M. \& Erdem, R. (2015). Informal communication process in organizations: a conceptual framework. Afyon Kocatepe University Journal of Economics and Administrative Sciences, 17(1), 125-139.

Blandul, C.V. (2015). Inovation in education - fundamental request of knowledge society. Procedia Social and Behavioral Sciences, 180, $484-488$

Brahier, B. R. (2006). Examining a model of teachers' technology adoption decision making: An application of diffusion of innovations theory. https://search.proquest.com/openview/e8a289eeec6ea2790a830015afc0f496/1?pqorigsite $=$ gscholar $\& \mathrm{cbl}=18750 \&$ diss $=\mathrm{y}$.

Bülbül, T. (2012). Development of innovation management scale in schools: validity and reliability study. Educational Sciences: Theory and Practice, 12(1), 157-175.

Central Executive Council of the Republic of Turkey / MYK (2015b/c). Turkey competency framework. Ankara, Türkiye. http://www.resmigazete.gov.tr

Commission of The European Communities (2008-2009). Commission Working Document: 1 Consultation On The Future "EU 2020" Strategy. https://www.cedefop.europa.eu/en/news-andpress/news/council-conclusions-22-may-2008-promoting-creativity-and-innovation-through.

Cornell University \& INSEAD (2019), Global Innovation Index 2019, GII, https://www.globalinnovationindex.org/gii-2019-report.

Creswell, J. W. (2007). Qualitative inquiry and research design. Thousand Oaks, California: Sage Publications.https://journals.sfu.ca/uwmadison/index.php/networks/article/view/62/65.

Çiftçi, S., Taşkaya, S. M. \& Alemdar, M. (2013). Classroom teachers' views on Fatih project. Ilköğretim Online, 12(1), 227-240.

Demir, S., Böyük, U. \& Koç, A. (2011). Science technology teachers' opinions on laboratory conditions and usage and their tendency to follow technological innovations. Mersin University Journal of Education Faculty, 7(2), 66-79.

Demirel, Y. \& Seçkin, Z. (2008). The effects of knowledge and knowledge sharing on innovation. Çukurova University Journal of Social Sciences Institute, 17(1), 189-202.

Dobni, C. B. (2008). Measuring innovation culture in organizations: the development of a generalized innovation culture construct using exploratory factor analysis, European Journal Of Innovation Management, 11(4), 539-559. 
European Trade Union Committee for education / ETUCE (2008). Teacher Education in Europe/ An ETUCE Policy Paper. http://ec.europa.eu.

European Commision/Directorate - General for Education and Culture (2010). The profession of teacher educator in Europe. Iceland. Key Data on teachers and school leaders in Europe. Eurydice Report. http://ec.europa.eu.

Filiz A. (2003). Innovation, innovation types, models and OSLO guide. Kaynak Electric Magazine, 170.

Günsel, A. \& Pelenk, E. S. (2017). The role of innovative human resource management practices in creating an innovation-oriented culture, International Journal of Tourism, Economics and Business Sciences, 1(2), 57-68.

Hesapçığlu, M. (2001), Education, School and Human Rights in the Postmodern / Global Society. (Ed. O. Oğuz, A. Oktay, H. Ayhan), Education and Turkish Education System in the 21st Century, İstanbul, 39-80.

Hesapçığlu, M. (2009), A historical analysis: Developments and predictions in education from 1923 to today, from today to 2023. Turkey Association of Private Schools (Ed.), Turkey's 2023 Vision Training Symposium Book, 127-139.

Herzog, P. (2011). Open and Closed Innovation: Different Cultures for Different Strategies. Germany: Gabler Verlag.

Hsu, C.L., Lu, H.P. \& Hsu, H. (2007). Adoption of the mobile internet: An empirical study of multimedia message service (MMS), International Journal of Management Science, 35(6), 715-726.

Karataş, S., Gök, R. \& Özçetin, S. (2015). Teacher perceptions of school administrators' innovation management competencies. Mehmet Akif Ersoy University Journal of Education Faculty, 1(33), 167185.

Karataş, H. (2018). Innovative teacher features: a scale development study. Uşak University Journal of Educational Research, 4(1), 34-57.

Kaya, S. (2017). Investigation of individual innovation levels of biology teachers. (Unpublished master thesis). Dicle University Institute of Educational Sciences.

Könings, K. D., Brand-Gruwel, S., \& van Merriënboer, J. J. (2007). Teacherse perspectives on innovations: Implications for educational design. Teaching and Teacher Education, 23(6), 985-997.

Kumral, O. \& Saracaloğlu, A. S. (2011). Evaluation of Education Programs and Educational Criticism Model. International Journal of Educational Programs and Instructional Studies, 1(2), 27 - 35.

Miles, M, B. \& Huberman, A. M. (1994). Qualitative data analysis: An expanded Sourcebook. (2nded). Thousand Oaks, CA: Sage.

National Science Board (2016/2017/2018). Science \& engineering 1ndicators https://www.nsf.gov/statistics/2016/nsb20161/uploads/1/nsb20161.pdf.

OECD (2005). OSLO Guide, Paris: OECD Publications.

Ospennikova, E., Ershov, M. \& Iljin, I. (2015). Educational robotics as an inovative educational technology. Procedia - Social And Behavioral Sciences, 214, 18 - 26.

Özdaşl1, K. (2010). Creating an innovative organizational structure in businesses: a multi-element model proposal. Turkey Social Studies Journal, 14(1), 93-110. 
Özmusul, M. (2012). Creativity and innovation in teacher education. Kastamonu Journal of Education, 20(3), 731-746.

P21 (2018). Partnershipfor 21 century skills. Retrieved from http://www.battelleforkids.org/about-us.

$\mathrm{Qu}$, J. \& Liang, L. (2010). Research on the methods for technological novation ability training of college students. IEE Computer Society DOI 10.1109/ETCS.2010.278.

Republic of Turkey Ministry of Education / MEB (2006-2008). Teacher competencies teaching profession general and specific field competencies. http://www.meb.gov.tr.

Sar1, M. (2011). Evaluation of Preservice Teachers' Opinions on the Place of the Laboratory in Teaching Primary Education Science and Technology Lessons and Science Experiments with Simple Tools and Equipment, 2nd International Conference on New Trends in Education and Their Implications. Antalya.

Taş, S. (2017). Innovation, education and global innovation index. Bilge International Journal of Social Research, 1(1), 99-123.

Thematic Network on Teacher Education in Europe /TNTEE (2000). Green paper on teacher education in Europe / high quality teacher education for high quality education and training. http://entep.unibuc.eu.

TÜSİAD (2003). TÜSİAD Annual Report. https://tusiad.org/tr/faaliyet-raporlari/item/2532-tusiadfaaliyet-raporu-2003

Tzafrir, S. (2003). The consequences of emerging hrm practices, trust in their managers, Journal of Personnel Review. 33, 624-647.

UNESCO (2002). Teacher Education Guidelines: Using Open and Distance Learning. p:7-8 http:// unesdoc.unesco.org/images/0012/001253/125396e.pdf. 20.04.2020.

Usluel, Y. K., Mumcu, F. K., \& Demiraslan, Y. (2007). ICT in the learning-teaching process: Teachers' views on the integration and obstacles. Hacettepe University Journal of Education, 32(32), 164-178.

Uz, A. \& Uz, N. (2018). Joseph Beuys, with his innovative and unusual aspects in education and arts, Journal of Eurasian Social and Economic Studies, 5(9), 48-58.

Ürper, Y. (2008). Entrepreneurship. Eskişehir: Anadolu University Publications.

Yıldırım, Z. Ş. (2010), Evaluation of novice teacher training program: Şanlıurfa example, (Unpublished master thesis). Marmara University. İstanbul.

Yıldırım, A. \& Şimşek, A. (2005). Qualitative research methods in the social sciences (5th ed.). Ankara: Seckin Publishing.

Yılmaz, H. \& Kocasaraç, H. (2010), A new income in a new in-service teacher education: teachers program and care, Ahi Evran University Faculty of Education Journal, 11(3), 51-64. 